\title{
IDENTIFIKASI PENGETAHUAN TRADISIONAL MASYARAKAT SENTANI DAN PELUANGNYA UNTUK PEMBELAJARAN FISIKA
}

\author{
Triwiyono" ${ }^{1)}$, Sudardja Adiwikarta ${ }^{2)}$ \\ ${ }^{1)}$ Program Studi Pendidikan Fisika, Universitas Cenderawasih, Jayapura, Indonesia \\ ${ }^{2}$ Sekolah Pascasarjana, Universitas Pendidikan Indonesia, Bandung \\ Email: y_triwiyono07@yahoo.co.id
}

\begin{abstract}
This research is aimed to investigate, to describe and to elaborate the system of traditional knowledge of Sentani society in Papua. Research method is qualitative. The conduction of the research has been done in forms of interview, field observation, and bibliography study that to spent four months. Respondents were chosen purposively. Some findings on traditional knowledge that related to physics are about ethnophysics, and transportation. The most important finding is that the traditional knowledge has not been able to explain all natural phenomena, moreover scientifically. For example solar-eclipse, lightning as an incredible mystical phenomena.
\end{abstract}

Keywords : traditional knowledge, Sentani society, phenomena.

\section{Pendahuluan}

Proses pembelajaran Ilmu Pengetahuan Alam (IPA) di sekolah, selain menggunakan teori psikologi yang berakar pada filsafat konstruktivisme dan perspektif sosiologi, para peneliti dan ahli pendidikan saat ini mencoba untuk menggunakan kajian teori anthropologi. Pandangan anthropologi ini mencoba melihat proses pembelajaran IPA di sekolah pada seting budaya masyarakat lokal (Wahyudi, 2007). Pembelajaran akan lebih bermakna bagi anak apabila materi yang dipelajari terkait dengan kehidupan keseharian anak. Pengaruh latar belakang budaya yang dimiliki siswa terhadap proses pembelajaran IPA ada dua macam. Pertama, pengaruh posistif akan muncul jika materi pada pembelajaran IPA di sekolah yang dipelajari selaras dengan budaya siswa seharihari. Kedua, proses pembelajaran IPA di kelas menjadi pengganggu ketika materi pelajaran IPA tidak selaras dengan latar belakang budaya siswa (Cobern dan Aikenheid, 1998;Aikenheid dan Jegede 1999 dalam Wahyudi,1990)

Secara umum budaya dipandang sebagai pengetahuan, keterampilan, kebiasaan, sikap dan kepercayaan, serta benda-benda hasil karya yang dihasilkan oleh sekelompok masyarakat yang ditransmisikan dari generasi ke generasi. Budaya adalah seluruh intelektualitas, kemasyarakatan, teknologi, politik, ekonomi, moral agama, dan sesuatu yang berkaitan dengan keindahan yang dimiliki manusia (Pai, 1990). Menurut Thaman (2001), budaya adalah suatu cara untuk mempertahankan hidup dari suatu masyarakat dengan kepemilikan pengetahuan, keterampilan, dan nilai-nilai yang digambarkan melalui bahasa serta ditransmisikan dari generasi ke generasi berikutnya untuk tujuan kelestarian budaya dan kelangsungan hidup. Koentjaraningrat (1990) menyatakan bahwa budaya adalah keseluruhan sistem gagasan, tindakan, dan hasil karya manusia dalam rangka kehidupan masyarakat yang dijadikan milik diri manusia dengan belajar. Berikutnya J.J. Honigman dalam Koentjaraningrat (1990) membedakan adanya tiga wujud budaya yaitu : (1) wujud budaya sebagai suatu kompleks ide, gagasan, nilai, norma, peraturan, dan sebagainya, (2) wujud budaya sebagai suatu kompleks aktivitas serta tindakan berpola dari manusia dalam masyarakat, dan (3) wujud budaya sebagai benda-benda hasil karya manusia. Ditambahkan juga bahwa terdapat tujuh unsur universal kebudayaan yang merupakan isi pokok kebudayaan di dunia yaitu : Bahasa, sistem pengetahuan, organisasi sosial, sistem peralatan hidup/teknologi, sistem mata pencaharian, sistem religi, dan kesenian.

Papua merupakan provinsi yang sebagian besar penduduknya hidup di daerah pedesaan yang memiliki ciri-ciri yang khas dan berbeda dengan daerah lain. Mereka tersebar dalam berbagai kelompok dimana masing-masing kelompok dan ekosistemnya melahirkan keragaman sifat-sifat penduduk setempat dalam hal budaya. Studi tentang pengetahuan tradisional pada masyarakat Papua, khususnya yang dilakukan oleh peneliti lokal sampai sekarang umumnya masih terbatas pada studi inventarisasi.

Dari hasil survey 12 responden guru fisika SMP di Sentani kabupaten Jayapura ditemukan bahwa $75 \%$ guru masih jarang mengkaitkan masalah nyata yang dialami siswa dalam melaksanakan pembelajaran. Hal itu memberikan gambaran bahwa belum adanya pemanfaatan secara optimal tentang sumber belajar lingkungan (budaya) dalam pembelajaran.

Berdasarkan pada permasalahan di atas maka tujuan penelitian ini adalah : (1) mendeskripsikan pengetahuan tradisional masyarakat Sentani, (2) 
mengidentifikasi pengetahuan tradisional masyarakat Sentani yang dapat dijadikan sebagai sumber belajar.

\section{Metode Penelitian}

Metode penelitian yang digunakan adalah metode kualitatif. Penelitian ini dilakukan di distrik Sentani kabupaten Jayapura selama empat bulan. Data dikumpulkan dengan teknik wawancara dan pengamatan langsung serta studi pustaka. Subyek dari penelitian adalah masyarakat asli Sentani. Responden dalam penelitian dipilih secara purposif.

\section{HaSIL DAN PEMBahasan}

\section{A. Pengetahuan Masyarakat Sentani Berkaitan dengan Alam dan Gejalanya}

\section{Petir (wili) dan Guntur (qurru)}

Petir dan guntur merupakan gejala alam yang luar biasa. Menurut orang Sentani petir dan guntur terjadi karena matahari murka yang disebabkan oleh perbuatan manusia. Mitos yang ada di masyarakat adalah sebagai berikut: Pada zaman dahulu hidup suatu keluarga baru pasangan suami-istri di pinggir danau kampung Netar. Pada suatu hari istrinya sedang tidur di para-para dibelakang rumahnya (waktu itu istrinya sedang hamil tua sekitar 8 -9 bulan). Pada saat ia sedang tidur terjadi kilat atau wili. Secara tibatiba kilat tersebut menyambar kepalanya hingga tewas di tempat. Setelah suaminya melihat kejadian tersebut ia segara melaporkan kepada masyarakat sekitar. Kemudian bersama-sama dengan masyarakat di kampung netar suaminya sepakat untuk menguburkan istrinya. Setelah dikubur janin dalam kandungan ibunya tumbuh dan berkembang sampai ia menjadi anak berumur antara 3-5 tahun. Anak ini sering keluar dari dalam kubur dan mengganggu anak-anak kampung.yang sedang bermain.Apabila mereka mengejarnya, maka anak itu masuk ke kubur ibunya, dengan begitu anak -anak kampung tidak bisa menangkapnya. Setelah beberapa saat terjadi hal yang sama secara sembunyi-sembunyi masyarakat mengintai, dan ternyata mereka menemukan anat itu benar-benar masuk ke dalam kubur ibunya. Kejadian itu dilaporkan kepada ayah dari anak tersebut. Ketika ayahnya mengetauhi bahwa itu anaknya maka dengan segera ia membawa pulang ke rumah dan tinggal bersama-sama. Setelah anak beranjak dewasa ia mulai mencari tahu pembunuh dari ibunya. Ayah dan neneknya, serta masyarakat kampung menceritakan bahwa ibunya dibunuh oleh petir. Setelah ia mengetahui bahwa pembunuh ibunya adalah petir, maka dengan segera ia pergi untuk mencari petir. Ia berjalan dari kampung ke kampung untuk mencari tahu keberadaan petir. Setelah ia mendapat imformasi tentang tempat tinggal petir, ia langsung menuju ke rumah petir. Sesampainya di rumah petir, didapatinya petir sedang tidur. Pada saat itu juga dengan senjata tajam yang di bawanya ia memotong leher petir hingga putus dan membawa pulang untuk dikubur. Ceritanya berakhir di sini. Menurut kepercayaan masyarakat di kampung netar dan masysrakat sentani pada ummunya atas kejadian tersebut, petir yang terjadi sekarang tidak memakan korban seperti yang terjadi pada zaman dahulu. Sebab pada zaman dahulu bila terjadi petir pasti memakan korban terutama manusia. Batu putih yang dianggap sebagai kepala petir sampai sekarang masih berada di netar di rumah ondofolo di kampung netar.

Mitos yang berkaitan dengan guntur dari kampung Hobong. Menurut masyarakat dikampung tersebut bila awan menutup kampung dan disertai guntur yang keras tanpa hujan, itu menandakan bahwa akan ada ondofolo atau koselo (bawahannya) akan meninggal dalam waktu 5-6 hari kedepan, atau bisa lebih cepat dari itu. Peristiwa ini masih sering terjadi hingga sekarang.

\section{Benda-benda Angkasa}

Pengetahuan masyarakat Senatni tentang bendabenda angkasa. Mereka menganggap matahari yang disebut dengan hu adalah dewa pemberi hidup. Benda angkasa lainnya seperti bulan yang disebut okho adalah sebagai pemberi terang di waktu malam. Begitu juga dengan bintang, bintang yang muncul menjelang malam disebut alohei dan bintang yang muncul menjelang pagi atau subuh disebut findlauyahei. Menurut mereka bintang yang sudah tua akan jatuh ke bumi dan kalau jatuh akan menghasilkan pancaran yang disebut dalo imobohe yang dikenal dengan meteor. Bila terjadi gerhana bulan atau gerhana matahari diyakini sebagai tanda bencana alam. Gerhana bulan disebut okho nemeobung, sedangkan gerhana matahari disebut hu nemeobung (Suraatmaja, 1991).

Mitos tentang matahari dan bulan dari kampung Yomoqo (Flassy, 2007). Pada suatu hari para lakilaki berburu dan bekerja di kebun. Di dalam kampung hanya ada perempuan dan anak-anak. Para perempuan itu sedang sibuk menganyam jala. Tidak jauh dari kampung itu terdapat sebatang pohon besar tempat dimana suatu makluk siluman atau hantu berdiam. Hantu itu turun dari pohon dan pergi ke kampung Yomoqo menggagahi para perempuan satu per satu. Kejadian itu akhirnya di ketahui oleh para lelaki. Pohon tempat berdiam hantu dibakar dan dengan peralatan benda tajam, panah, parang dan sebainya para lelaki menyerang hantu yang telah keluar dari pohon. Akhirnya salah satu dari mereka berhasil mencungkil mata kiri hantu dan menombaknya. Hantu lenyap masuk ke dalam air dan muncul di arah matahari terbit (timur). Hantu bertanya kepada salah satu lelaki (Hoboi), di manakah aku sekarang? Lalu Haboi menjawab,'Dirimu sekarang matahari, sedang mata kirimu yang telah dicungkil keluar itu adalah bulan. Mula pertamanya keduanya matahari dan bulan bergerak dari atas (utara) ke bawah (selatan). Begitu jatuh haripun gelap, malam tiba. Kali keduanya 
bergerak dari bawah (selatan) ke atas (utara). Kali ketiganya bergerak dari barat ke timur. Kali keempatnya keduanya bergerak dari timur ke barat dan tetaplah adanya hingga sekarang.

\section{Gempa bumi dan Pelangi}

Tidak seperti ditempat lain di jawa misalnya, orang Sentani tidak memiliki ceirta atau mitos tentang gempa bumi dan pelangi. Peristiwa gempa bumi (onyeu) menurut orang sentani menandakan akan terjadi perubahan musim, dari musim panas ke musim penghujan atau sebaliknya. Onyeu artinya matahari mulai berbalik arah, dari utara ke selatan atau sebaliknya. Menurut mereka juga terjadinya gempa bumi menandakan adanya musibah seperti penyakit. Bila setelah terjadi gempa bumi banyak ikan yang mati maka diyakini bahwa wabah yang datang terjadi pada ikan, tetapi jika setelah terjadi gampa bumi banyak penyakit yang menyerang manusia, maka wabah yang terjadi melanda manusia. Pelangi yang disebut yahamflaham menurut orang Senatni menandakan datangnya musim hujan dan buah-buahan. Warna pelangi menggambarkan warna buah-buahan

\section{a. Pengetahuan Masyarakat Sentani yang Berkaitan dengan Warna, Bunyi, dan Bayangan}

Menurut orang Sentani warna terbagi menjadi warna merah (haisay), putih (kleumom), biru (okhebu), kuning (yanggo), hijau (ovebu), dan hitam (nokhomom). Warna merah banyak digunakan sebagai lambang keberanian dalam perang dan tanda bahaya atau kematian karena kecelakaan.

Bayangan yang disebut dengan unulu merupakan bayangan roh manusia yang kelihatan. Maka bayangan manusia tidak boleh berada di bawah bayangan manusia yang lain. Kemudian getaran yang keluar dari mulut mereka sebut a atau suara. Disebut a karena menurut mereka bila kita berbicara pasti mulut kita bergetar. Apabila ada suara terdengar dari seberang gunung atau seberang danau setelah teriakan. Suara seperti itu disebut anuju. Menurut mereka suara itu tidak boleh ada karena sudah keluar dari tubuh. Masih berkaitan dengan bunyi, masyarakat Sentani dari Zaman dahulu hingga sekarang dalam acara-acara resmi atau acara adat menggunakan alat musik pukul tifa. Tifa adalah alat musik tradisional seperti gendang (di jawa).

\section{b. Pengetahuan Masyarakat Sentani Mengenai Pengukuran}

Untuk mengukur jarak ada hubungannya dengan anggota tubuh mereka seperti depa yang disebut meyalo. Meyalo setara dengan meter, untuk ukuran yang setara dengan $\mathrm{cm}$ mereka menggunakan ruas tubuh yang mereka sebut dengan yu pohi. Meyalo dan yu pohi juga digunakan untuk mengukur panjang perahu, tiang rumah, dan jarak. Untuk mengukur jarak kadang-kadang mereka berpatokan pada alam seperti tanjung atau teluk.

Selain itu untuk menentukan jarak yang jauh sewaktu bepergian mereka berpatokan dengan waktu yaitu pagi hari (rene), siang hari (rai), dan malam hari (riniai). Batas waktu rene pukul 6 pagi sampai 10 pagi, rai pukul 11 siang sampai 2 siang, sore hari (huwarai) pukul 3 sore sampai 6 sore, riniai pukul 7 malam sampai 12 malam, pagi pukul 12 sampai 3 pagi dinamakan riniai nolo, dan subuh (yarahei) pukul 3 pagi sampai 5 pagi. Untuk mengukur panjang, lebar, dan tinggi rumah mereka juga sering menggunakan alat bantu batang tebu yang disebut yu himbai.

\section{Alat Transportasi Masyarakat Sentani}

Masyarakat Sentani yang tinggal di sekitar danau menggunakan alat transportasi perahu dayung. Masyarakat Sentani membedakan jenis perahu dayung untuk wanita dan laki-laki. Pembuatan perahu dilakukan di tempat di mana pohon yang akan dibuat perahu itu ditebang. Pemilihan jenis kayu dipilih kayu yang memiliki berat jenis kecil dan tahan lama, jenis kayu yang memenuhi kriteria tersebut adalah kayu matoa, kayu bitangor, kayu raime. Bagaimana mereka membawa perahu bila tempat pembuatannya jauh dari danau. Sekelompok orang yang terdiri dari kaum lakilaki, sewaktu menarik perahu dibagi menjadi beberapa kelompok; sebagian anggota kelompok ada yang menarik dan mendorong perahu, sedangkan sebagian yang lain mengumpulkan ranting dan daun yang ditemukan di sepanjang jalan. Ranting dan daun tersebut diletakkan didepan perahu agar perahu mudah ditarik. Setelah perahu berhasil ditarik sampai di tepi danau, seorang pemahat kayu mengukir perahu dengan motif lokal Sentani.

Pengetahuan tradisional masyarakat Sentani tentang petir dan guntur. Petir dan guntur terjadi karena matahari murka akibat perbuatan manusia. Secara ilmiah dapat dijelaskan bahwa petir atau kilat merupakan gelombang elektromagnetik, sedangkan guntur merupakan gelombang mekanik. Demikian pula pengetahuan tradisional masyarakat Sentani tentang pelangi. Pelangi menunjukkan musim hujan dan warna pelangi menunjukkan warna buah-buahan. Secara fisika pelangi terjadi karena proses pembiasan. Cahaya matahari yang merupakan cahaya polikromatik dibiaskan oleh titik air di udara sehingga terurai menjadi warna penyusunnya yaitu merah, jingga, kuning, hijau, biru, nila, dan ungu yang disebut dengan pelangi. Pengetahuan tradisional masyarakat Sentani tentang gerhana matahari dan gerhana bulan, peristiwa tersebut sebagai tanda bencana atau musibah. Secara ilmiah gerhana matahari dan gerhana bulan terjadi ketika posisi matahari, bumi dan bulan terletak dalam satu garis lurus. Tjasyono (2006), apabila pada waktu bulan purnama bumi berada diantara matahari dan bulan, sehingga bayangan bumi mengenai bulan maka 
terjadi gerhana bulan. Tetapi jika bulan terletak diantara matahari dan bumi pada waktu bulan baru sehingga bayangan bulan mengenai bumi maka terjadi gerhana matahari.

Pengetahuan tradisional masyarakat Sentani tentang matahari dan bulan. Matahari dianggap sebagai dewa pemberi hidup dan bulan dewa pemberi terang di malam hari. Daryanto (2007), sumber energi utama untuk semua makhluk hidup di bumi ini adalah matahari. Matahari memancarkan sinar terus menerus ke bumi, karena itu sinar matahari merupakan arus energi yang dipancarkan bagi kehidupan.Sebagai contoh fotosintesis yang terjadi pada tumbuhan memerlukan bantuan sinar matahari. Bulan sebagai pemberi terang di malam hari. Pengetahuan tradisional masyarakat Sentani memandang bahwa bulan memancarkan cahayanya sendiri diwaktu malam hari. Menurut ilmu fisika bulan adalah benda langit yang tidak memancarkan cahaya. Bulan memantulkan cahaya matahari yang sampai ke bumi di waktu malam hari. Pengetahuan tradisional masyarakat Sentani tentang bintang adalah bahwa bintang yang tua akan jatuh ke bumi yang disebut delo imobohoe atau sekarang dikenal dengan meteor. Pengetahuan tentang bintang jatuh dapat dijelaskan secara ilmiah. Menurut Tjasyono (2006), meteor adalah fenomena emisi cahaya dalam atmosfir bumi. Meteor menukik ke dalam atmosfir dengan kecepatan antara $11 \mathrm{~km} /$ detik sampai dengan $72 \mathrm{~km} /$ detik, kemudian terbakar pada ketinggian sekitar $100 \mathrm{~km}$. Meteor sering disebut dengan bintang jatuh (Tjasyono, 2006); VanCleave, 2002). Benda langit yang beterbangan secara tidak teratur dengan orbit tidak tetap dan tidak bercahaya disebut meteorid. Meteorit yang jatuh karena gaya tarik bumi akan berpijar akibat gaya gesekan atmosfir bumi.

Pengetahuan tradisional masyarakat Sentani tentang warna. Masyarakat Sentani mengenal berbagai macam warna. Kesan warna secara fisika dapat dijelaskan melalui peristiwa pemantulan dan penyerapan cahaya. Sebagai contoh kita dapat melihat warna suatu benda kelihatan hijau karena benda tersebut memantulkan warna hijau yang sampai pada mata kita, sedangkan warna lain diserap benda tersebut.

Masyarakat Sentani menyebut getaran yang keluar dari mulut adalah a atau suara. Kemudian mereka juga mengetahui adanya suara setelah teriakan yang disebut anuju. Secara fisika bunyi dapat dihasilkan oleh adanya getaran suatu benda dan bunyi merupakan gelombang yang sifatnya dapat dipantulkan apabila dan penjalarannya terhalang oleh suatu benda. Tifa adalah salah satu contoh alat musik tradisional yang dapat menghasilkan bunyi. Secara fisika bunyi yang dihasilkan oleh tifa dapat dijelaskan dengan konsep resonansi.

Secara tradisional masyarakat sentani mennggunakan alat ukur sederhana yang menjadi alat bantu mereka dalam memecahkan masalah. Dalam pembelajaran fisika metode pengukuran tradisional masyarakat Sentani dapat dijadikan sebagi sumber belajar pada waktu guru menyajikan pokok bahasan besaran dan satuan.

Hal lain yang perlu dicermati dalam temuan penelitian ini adalah bahwa meskipun masyarakat Sentani tidak mengenal tentang konsep gaya gesek, namun dalam kehidupannya mereka telah menerapkan prinsip gaya gesek. Contoh, orang Sentani dalam menarik perahu berusaha memperkecil gaya gesek agar perahu yang ditarik terasa lebih ringan. Masih berkaitan dengan konsep gaya, alat transportasi dengan menggunakan perahu dayung. Perahu dayung dapat berjalan dapat dijelaskan dengan hukum III Newton.

\section{PENUTUP}

Temuan pengetahuan tradisional masyarakat Sentani dalam penelitian ini dapat dikelompokkan ke dalam etnofisika dan tranportasi. Pengetahuan etnofisika meliputi pengetahuan tentang petir, guntur, benda angkasa, gempa bumi, pelangi, warna, bunyi, bayangan, dan pengukuran. Pengetahuan tradisional Masyarakat Sentani belum bisa menjelaskan seluruh fenomena alam, apalagi penjelasann secara ilmiah.

\section{UCAPAN TERIMA KASIH}

Ucapan terima kasih kami sampaikan kepada Debora Sokoy, Yaneke Ibo, Stince Deda, Frans Mokay, Simson Ibo, Max Yoku, Yosia Mehue, Soni Ibo, Hf Ali Tokoro atas informasi pengetahuan tradisional masyarakat Sentani yang diberikan. Steven Ibo yang telah banyak membantu dalam pengambilan data.

\section{REFERENSI}

[1] Daryanto. (2007). Energi. Yogyakarta : Pustaka Widyatama.

[2] Flassy,D.a.l. (2007). Etno Artistik Sentani : Motif Gaya Rias. Jakarta: Balai Pustaka.

[3] Koentjaraningrat. (1993). Irian Jaya Membangun Masyarakat Majemuk. Jakarta : Gramedia Pustaka Utama.

[4] Pai, Y. (1990). Cultural Foundations of Education. New York : Macmillan Publishing Company.

[5] Suraatmaja, B. dan Warip, M. (1991). Sistem Pengetahuan Masyarakat Sentani. Laporan Penelitian Uncen Jayapura. Tidak diterbitkan.

[6] Thaman, K.H. (2001). Towards Culturally Inclusive Teacher Education With Spesific Reference To Oceaniua. International Education Journal. Vol. 2 No. 5.

[7] Tjasyono, B. (2006). Ilmu Kebumian dan Antaraiksa. Bandung: PT. Remaja Rosdakarya. 
[8] VanCleave, J. (2002). A+ Projects in Astronomy Winning Experiments for Science Fair and Extra Credit. John Wiley \& Sons, Inc
[9] Wahyudi .(2007). Kurikulum IPA Berbasis Budaya Lokal. http://www.duniaguru.com diakses 19 Februari 2007 